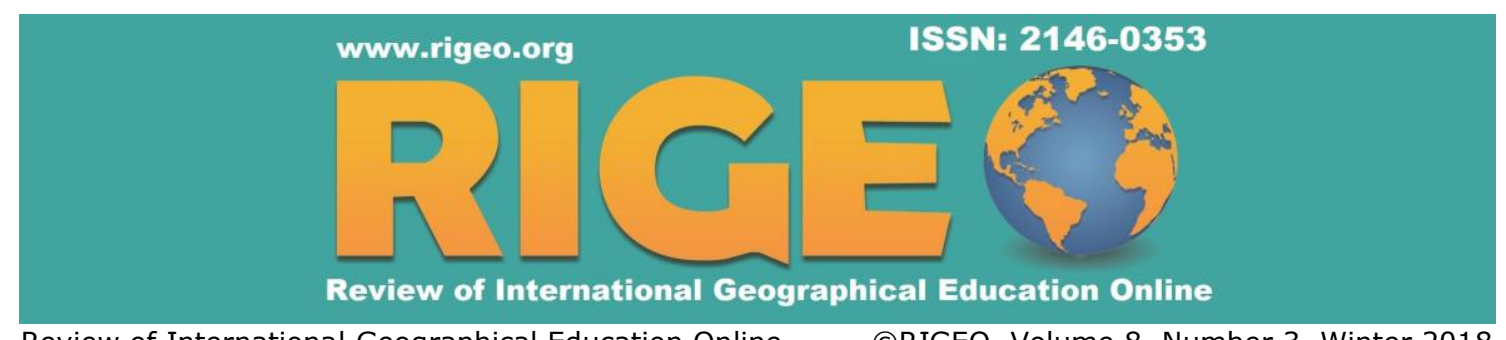

Review of International Geographical Education Online

(C) RIGEO, Volume 8, Number 3, Winter 2018

Research Article

Copyright $\odot$ RIGEO 2018

To cite this article: Regelous, T.; Holzförster, F.; Stich, A. (2018). Mobile Phones As Gold Deposit - Students Explore Sustainability in a Hands-on Project. Review of International Geographical Education Online (RIGEO), 8 (3),459-472, Retrieved from http://www.rigeo.org/vol8no3/Number3winter/RIGEO-V8-N3-3.pdf

Submitted: March 29, $2018 \quad$ Revised: July 19, $2018 \quad$ Accepted: November 15, 2018

\title{
Mobile Phones as Gold Deposit-Students Explore Sustainability in a Hands-on Project
}

\author{
Anette REGELOUS ${ }^{1}$ \\ University of Erlangen-Nürnberg (FAU), Erlangen, GERMANY \\ Frank HOLZFÖRSTER ${ }^{2}$ \\ GEO-Zentrum an der KTB, Windischeschenbach, GERMANY
}

Alexander $\mathrm{STICH}^{3}$

Hans-Böckler Schule, Fürth, GERMANY

\begin{abstract}
Resources, resource efficiency and sustainability are one of the most important socio-political issues of today. We here present a best practice example for project-based learning aiming to change student's understanding and attitude towards sustainability at school level. In this project forty-two Year 9 students explored by themselves the link between resources, sustainability and the consequences for their own living environment. After an introductory school seminar the students washed gold in a stream using gold washing pans. Afterwards, the students developed a hands-on model how gold deposits form and carried out experiments concerning the physical and chemical properties of gold. At the University the students then analysed the chemical composition of rocks containing gold. The learning outcomes were measured by a self-designed questionnaire. The results of the questionnaire before and after the project show that the students understood that mobile phones are "a valuable gold deposit" and appreciated the value of the precious metal gold as a high-tech raw material. Before the project only $24 \%$ of the students thought they had a good or very good understanding of the interrelationship between resources and sustainability, but after the project the percentage has been risen to $96 \%$. In addition, the students realized the value of recycling as an important aspect of sustainability. Only 5\% of the students stated that they would recycle their mobile phones before the project, after the project the percentage has increased to $67 \%$. The students took action in their school demonstrating a change in attitudes towards sustainability.
\end{abstract}

${ }^{1}$ Corresponding author: Dr., University of Erlangen-Nürnberg (FAU),Naturwissenschaftliche Fakultät, GeoZentrum Nordbayern, Schlossgarten 5, 91054 Erlangen, Germany, anette.regelous [at] fau.de

2Dr. habil.,GEO-Zentrum an der KTB, Am Bohrturm 2, 92670 Windischeschenbach, Germany, holzfoerster [at] geozentrum-ktb.de 3Hans-Böckler Schule, Fronmüllerstr. 30, 90763 Fürth, Germany, stich.alexander [at] hans-boeckler-schule.de

(C) Review of International Geographical Education Online RIGEO 2018 ISSN: 2146-0353 Www.rigeo.org 


\section{Keywords}

Sustainability; School Project; Mobile Phone; Education for Sustainable Development; Project Based Learning

The increasing world population, the increasing usage of resources and energy consumption, especially in the emerging markets, leads to a significant rise in the demand of raw materials and geogenic deposits. This situation creates a worsening of ecological, economic, social and political problems at a global level. The European commission states "Resources are the backbone of every economy. In using resources and transforming them, capital stocks are built up which add to the wealth of present and future generations. However, the dimensions of our current resource use are such that the chances of future generations - and the developing countries - to have access to their fair share of scarce resources are endangered. Moreover, the consequences of our resource use in terms of impacts on the environment may induce serious damages that go beyond the carrying capacity of the environment. These effects risk being aggravated once the developing world has taken up growth and resource use similar to the industrialized countries.”(http://ec.europa.eu/environment /index_en.htm). In Germany, the Federal Ministry of Education and Research announced on the 18th August 2014 "In view of the growing global demand for raw materials and the major economic and financial policy challenges facing Germany, the resource efficiency potential for the economy must increase and new perspectives evolve".

In view of the intensified discussion about sustainability, its relation to the depletion of natural resources and the need to seek solutions for the future, it is essential to sensitize students for this topic and to stimulate them to reflect on their own behavior (e.g. Huckle and Sterling, 2014, Blewitt and Cullingford, 2004). Interestingly, the role of geography in education for sustainable development in higher education shows great heterogeneity between different teacher training programs (Sprenger and Nienaber, 2017). In education for sustainable development Geography plays a major role at school (Haubrich, 2007) and most of the school curricula in Europe list resources within the environmental policy discussion (Kivinen, 2013), without, however, addressing the actual scope within the context of the student's life. One possible perspective is recycling of advanced technology products (Ballester et al. 2017), as electronic waste has a major contribution to the waste stream since advanced technology products are growing rapidly (MPFS, 2010, Hagelüken, 2013, Huy et al. 2015, Vergara \& Tchobanoglous, 2012; Widmer et al., 2005, Fairphone 2017). However, people only recycle a small amount of electronic items, e.g. less than $10 \%$ of people have recycled their old mobile phones (Chancerel, 2010, Tanskanen, 2012, Welfens et al. 2013). It is therefore essential to further enhance the students' understanding and knowledge about sustainability. Thus, we designed a school project integrated in the geography curriculum. The theoretical approach of the project is based on the concept of projectbased learning (PBL), as it has been shown that developing the students' independence and autonomy in learning is essential (e.g. Boud, 2012, Thomas, 2000). "Project-based learning (PBL) is a model that organizes learning around projects. According to the definitions found in PBL handbooks for teachers, projects are complex tasks, based on challenging questions or problems, that involve students in design, problem-solving, 
decision making, or investigative activities; give students the opportunity to work relatively autonomously over extended periods of time; and culminate in realistic products or presentations" (Jones, Rasmussen, \& Moffitt, 1997; Thomas, Mergendoller, \& Michaelson, 1999).

Cooper and Murphy (2016) state in their book "Hacking project based learning" that even though PBL is popular it is rarely undertaken in schools. Even though a lot of effort is made most projects only remotely approach PBL, because of the complexity of PBL. This implies that there is a necessity for PBL best practice examples. We therefore present a best practice example for a project-based learning project in order to change student's understanding and attitudes towards sustainability at school level. In this hands-on project the students examine autonomously the relation between sustainability and natural resources on the basis of their smartphone and thus in their own living environment. In this project, Year 9 students investigated by themselves, supported by their teacher, the link between resources, sustainability and the consequences for their own living environment. They used the opportunities provided by the natural site for rock sample collection, the geoscience outreach center "GEO-Zentrum an der KTB" specialised in geological education at school level, to gain the fundamental geological understanding and the GeoZentrum of the University Erlangen-Nürnberg to measure the gold contained in their samples.

\section{Methodology}

\section{Research Aim}

The aim of the project is to discover if this PBL approach changes the students' understanding and attitude towards sustainability. This project was therefore designed for students to question, explore and understand by themselves the relation between the occurrence of geo-natural resources, their efficient use and the associated aspects of sustainability as well as the economic value of the resource. The students then deduced from their results the environmental and social impact of the extraction and use of resources (Schmidt-Bleek, 2007, Lettenmeier et al., 2013, Liedtke et al., 2013, 2014). In order to create a link to every day's life, we chose the smartphone as example, as it is the modern instrument of information and telecommunication technology and also constantly present and important in the student's life (e.g. Wilska, 2003, Kuhlhay, 2013). The smartphone consists of more than 60 different chemical elements and has a metal concentration between 25 and 29\%. We selected the element Gold as an example, as gold placer deposits can be found in a day trip distance from the school (Lehrberger, 1997, Bayerisches Landesamt für Umwelt, 2017) and as gold is an essential component of the smartphone with $0.034 \mathrm{~g}$ per device (e.g. Hagelüken, 2011). On average one ton of gold ore contains as much gold as 40 mobile phones (Bayerisches Staatsministerium für Umwelt und Gesundheit Web Page (accessed on 23 January 2018). It is estimated that in Germany alone there are about 100 million unused mobile phones (BITKOM (accessed on 23 January 2018)) that contain together $2 \mathrm{t}$ of gold. Altogether there is approximately 5000t of electronic waste each year - most of it does not get back into global material cycles (Hagelüken et al., 2009). 
Regelous, A., Holzförster, F., Stich, A. (2018) / Mobile phones as gold deposit - students explore....

\section{Educational Design}

This project was consequently designed as a PBL best practice example to encourage students to act by themselves. Following the requirements of education for sustainable development (e.g. Haubrich, 2007), they were exposed to theoretical input, active efforts in nature, scientific work in nature and in laboratory environments and eventually took action in order to hand on their newly gained knowledge in the school environment. The project combined a variety of school subjects, e.g. geography, physics, chemistry, mathematics, economics, language, with manual work in the small mining sector. For the students the various and most of the time separate school subjects needed to connect in the certain application they worked on.

In order for the students to discover by themselves that old smartphones are an economically valuable, sustainable gold deposit, we designed a project consisting of six phases:

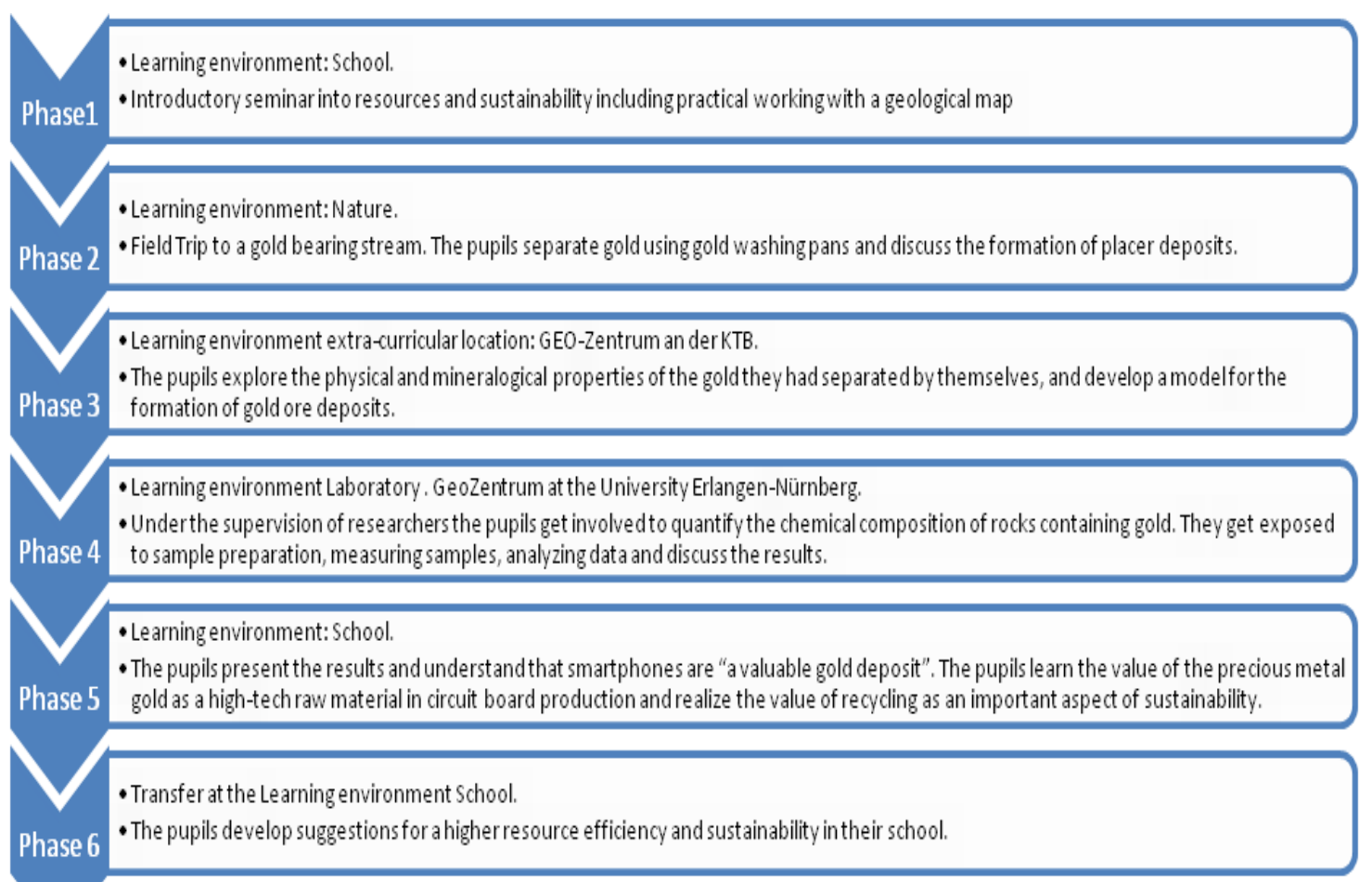

Figure 1. Flow chart illustrating the educational phases of the project

The project started with an introductory seminar given by the teacher at school in which the students gained an understanding of resources, resource efficiency and sustainability. This unit also included practical working with a geological map.

After the theoretical introduction the students attended a field trip to a gold-bearing stream cutting through palaeozoic basement rocks of the Bohemian Massif of eastern Bavaria (Lehrberger 1997, Bayerisches Landesamt für Umwelt 2017) and separated gold by themselves using gold washing pans. During this phase the students slipped in the role of active Argonauts and got actively involved in the project. In this learning 
situation the group came up with questions like "Why do I find gold in this stream?", "What is an ore deposit?", "When in Earth's history do gold deposits form, how long do they take to form and what is the link to sustainability?" and discussed these within the group and with the scientist from the University. This showed that the group started to think actively about the formation of placer deposits.

In order to find out the physical and chemical properties of gold, the students examined and explored the gold they sampled at the extra-curriculum institute "GEOZentrum an der KTB" supported by their teacher and the scientist. Using this knowledge they created and built a model how gold deposits form, by adapting an already existing experiment involving the geological principles of plate tectonics and global heat transfer. This encouraged them to develop ideas for the geological requirements that this raw material appears in nature.

At the GeoZentrum of the University of Erlangen-Nürnberg (FAU) the students then analyzed the chemical composition and gold concentration of gold-bearing rocks. The analyses were carried out by $x$-ray fluorescence. The students helped preparing the samples and carried out the measurements under constant support and supervision of the scientist. The students evaluated and discussed the collected data in groups. This led to questions about economical aspects of profitability. The students compared the gold concentration in gold-bearing rocks and mobile phones and understood that mobile phones can be seen as gold deposits.

After gathering all results the students presented them in a power point presentation at their school. They showed their independent and self-responsible research in the field, at the extra-curricular location, at university and at school and their results regarding the relation between resources, ore deposits, profitability and sustainability. They also presented their concept and suggestions for a better resource efficiency and sustainability under the perspective of recycling and they recognized their own responsibility in view of resources. In addition, they took action and implemented a smartphone collecting box in their school and advertised for it.

\section{Data Collection Method}

In order to measure how this project based on a PBL approach changes student's attitude and understanding of sustainability at school level, we designed a questionnaire that the students filled in before and after the project. Forty-two Year 9 students were involved in the project. The course was undertaken from June to July 2017 within the geography curriculum at the Hans-Böckler-Realschule in Fürth, Germany. The class consisted of 20 boys and 22 girls. In order to measure the learning outcomes, the students filled in a questionnaire designed by the researcher from the FAU after a first introduction to the topic in phase 1 and the questionnaire with the same questions at the very last step of phase 6 of the project. To ascertain that the measurements are reliable and valid the questionnaire design is based on the Harvard University Program on Survey Research (2018). The main focus hereby was to measure in which aspects the students increased their awareness, their knowledge and understanding and how they evaluated the project and themselves. The questionnaire was anonymous and not 
personalized. Therefore the students were able to write down their answers without the feeling that their answers would influence the grading after the project.

\section{Findings and Discussion}

In order to measure the learning outcomes the students were asked whether they have an idea about resources, sustainability and the link between them. Before the project, only $24 \%$ of the students thought to have a good or very good understanding of the interrelationship between resources and sustainability. However, after the project the percentage has risen to $96 \%$ (Fig. 2).

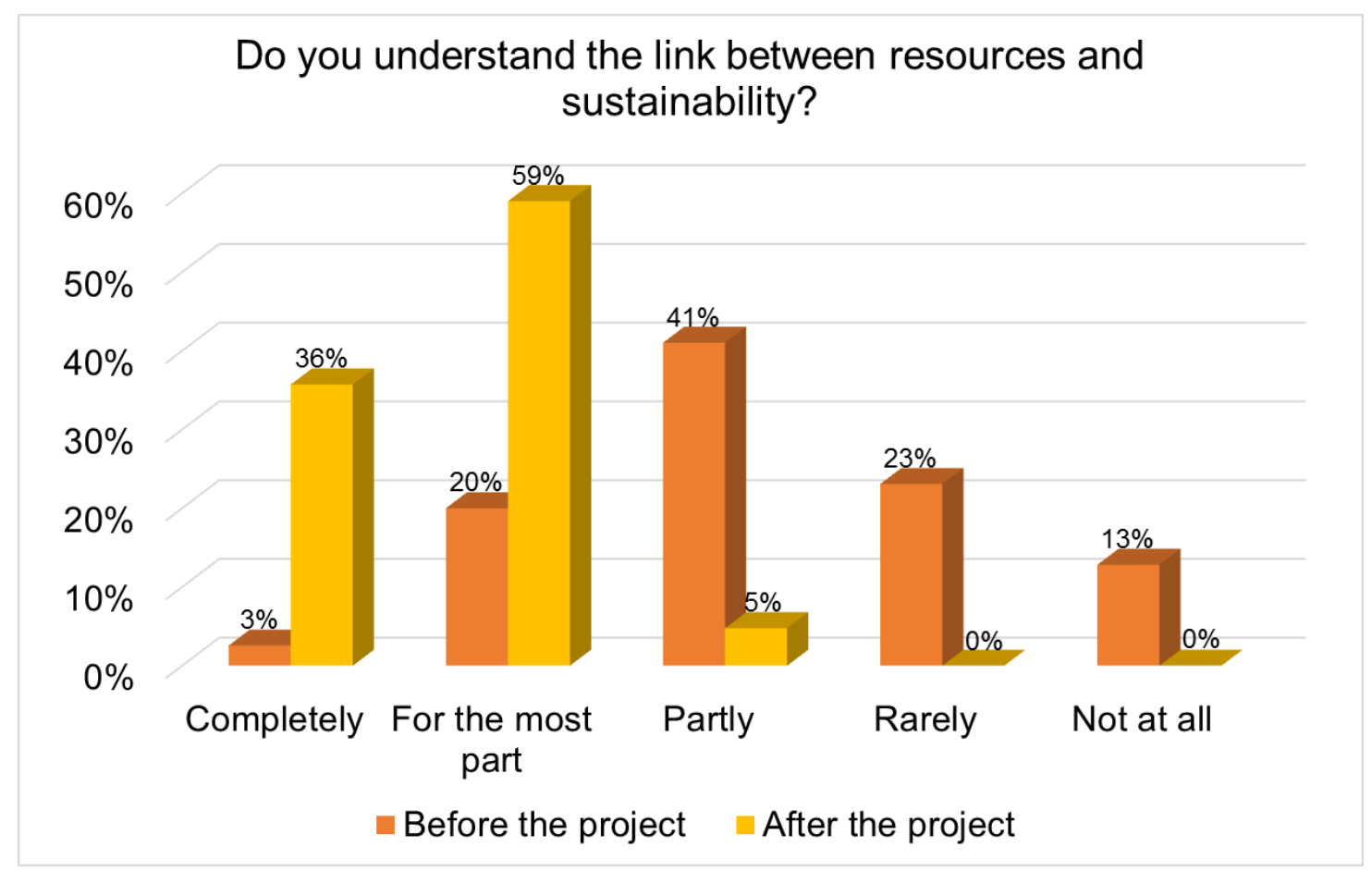

Figure 2. Distribution of answers $(\mathrm{n}=42)$ to the question "Do you understand the link between resources and sustainability?"

In addition, the students were significantly more concerned about the resource consumption of mankind after the project than before (Fig. 3). However, the diagram also shows that the awareness about resource consumption was already quite high before the project, as only 5\% stated that they are not or little concerned. Moreover, the shift towards more solicitude during the project gives the impression that the students were shocked from their own findings during the project. These results show that the project had a significant impact not only on the state of knowledge, but also on the awareness about resource consumption. 


\section{Are you concerned about the resource consumption of mankind?}

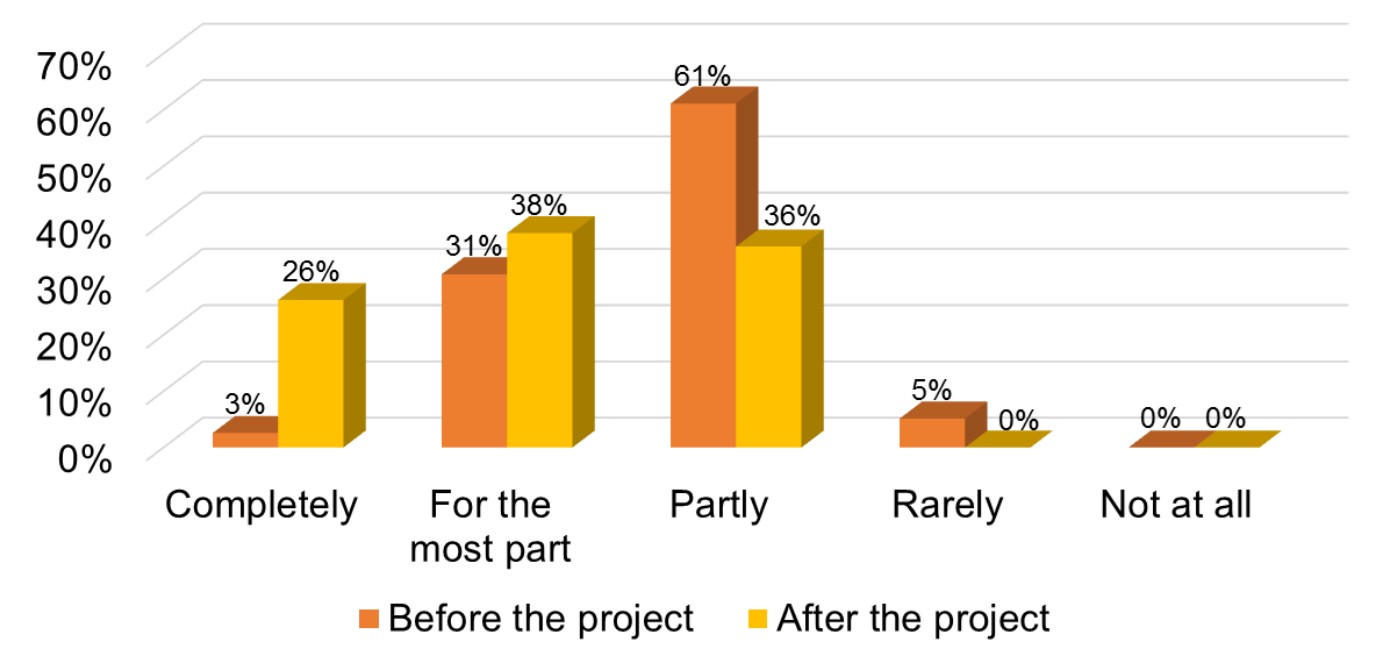

Figure 3. Distribution of answers $(\mathrm{n}=42)$ to the question "Are you concerned about the resource consumption of mankind?"

The questionnaire also tested the most important learning outcomes and the increase of knowledge, by asking the students whether their mobile phone contains gold (Fig. 4), whether they understand how gold deposits form (Fig. 5), whether one ton of gold ore contains on average less gold than one ton of smartphone scrap (Fig. 6). The results show that most students reached the educational objectives. However, as can be seen in Figure 6, 17\% did not reach the objective. One explanation could be that that not students can be reached through one teaching approach.

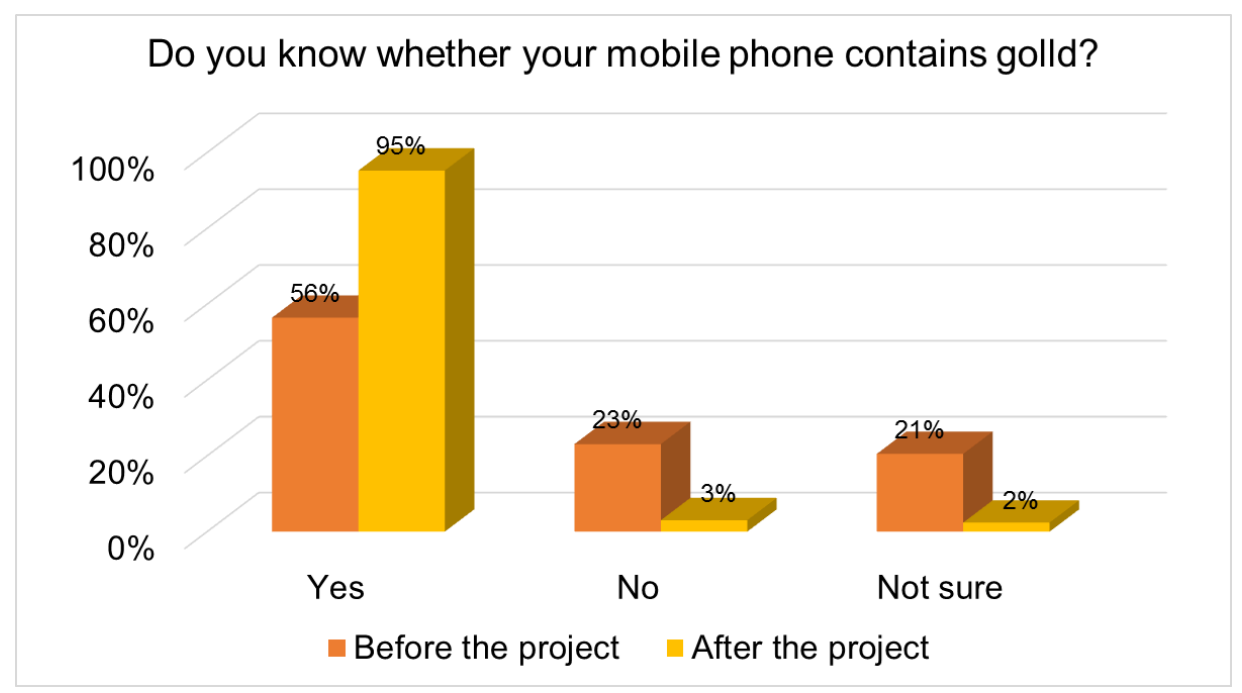

Figure 4. Distribution of answers $(\mathrm{n}=42)$ to the question "Do you know whether your mobile phone contains gold?" 


\section{Do you know how gold deposits form?}

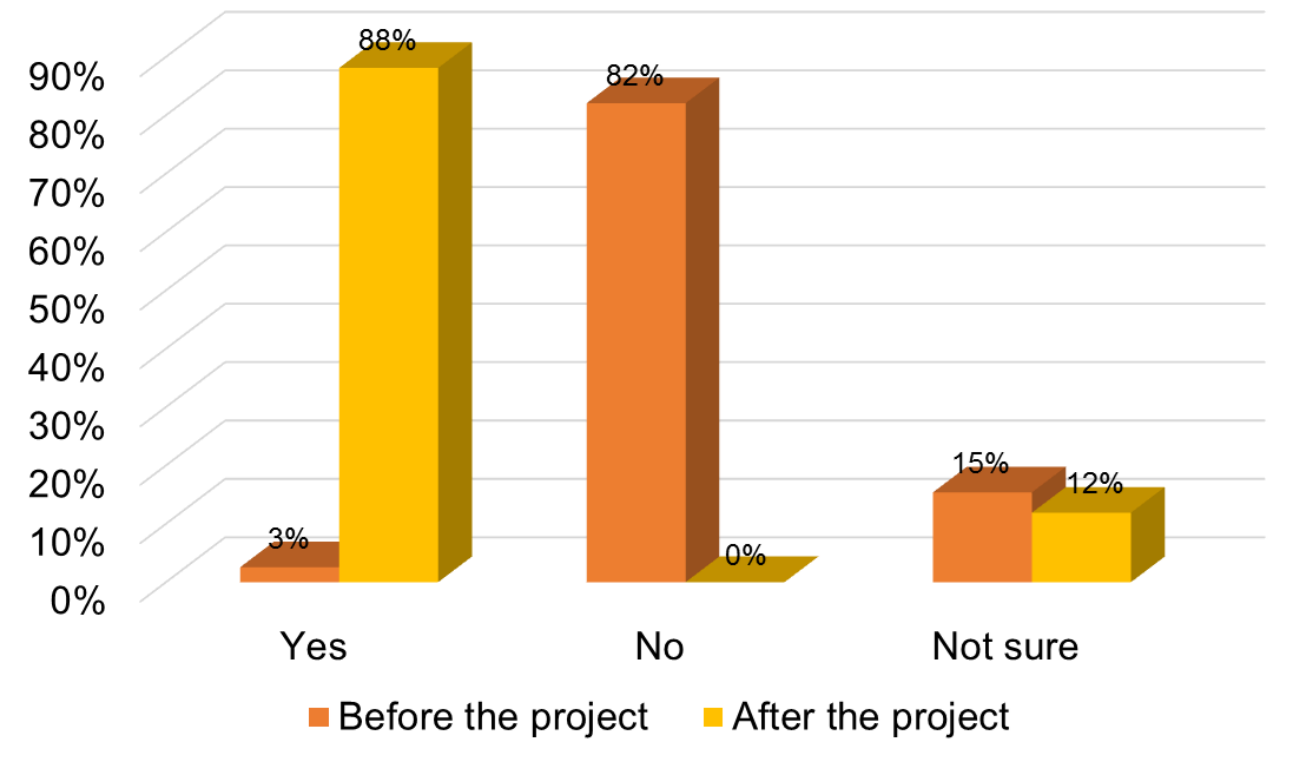

Figure 5. Distribution of answers $(\mathrm{n}=42)$ to the question "Do you know how gold deposits form?"

\section{Which contains more gold? One ton of ore or one ton of smartphone scrap metal?}

$80 \%$
$70 \%$
$60 \%$
$50 \%$
$40 \%$
$30 \%$
$20 \%$
$10 \%$
$0 \%$

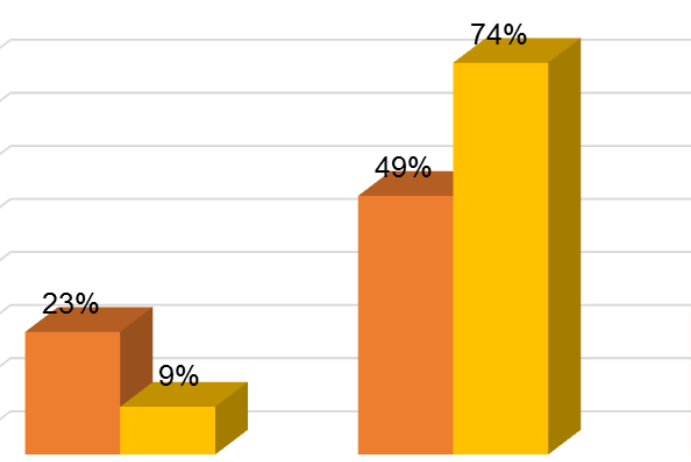

Gold ore

\begin{abstract}
Smartphone scrap metal
\end{abstract}

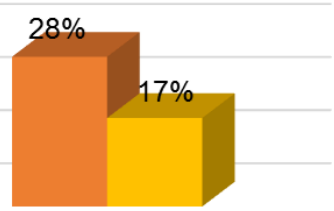

Not sure

Before the project $\quad$ After the project

Figure 6. Distribution of answers to the questions "Which contains more gold? One ton of ore or one ton of smartphone scrap metal?" 
Do you think that the worldwide natural gold deposits last for the human needs till the end of your life?

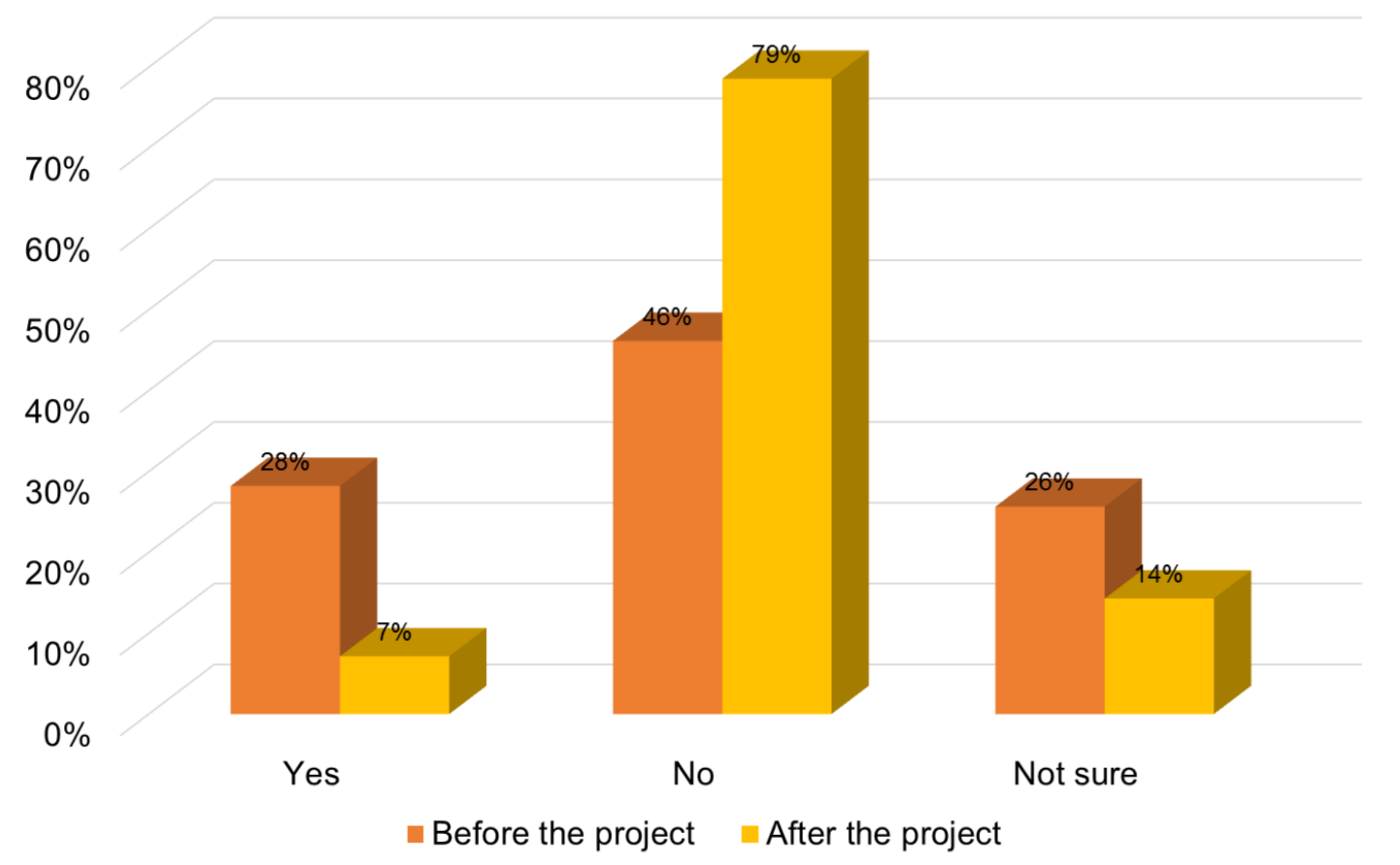

Figure 7. Distribution of answers to the question "Do you think that the worldwide natural gold deposits last for the human needs till the end of your life?"

By using a PBL approach and changing teaching methods as outlined in figure 1 , the issue of young people's behavioral patterns concerning mobile phones was approached carefully (Flick, 2013; Jonson et al., 2007; Tashakkori \& Teddlie, 2002; Welfens et al., 2013). In order to test whether the project-based learning has changed the student's understanding and behavior concerning sustainability they were asked what they intend to do with their old mobile phones after they replaced an old one. At the beginning of the project only $5 \%$ of the students stated that they would recycle their mobile phones, after the project $67 \%$ of the students wanted to do that (Fig. 8). That shows that their awareness concerning resources and sustainability has been enhanced significantly by the project. Students also realized that mobile phones contain enough gold to make them a gold deposit themselves (Fig. 6). They therefore appreciated that recycling is important and understood the link between recycling and sustainability. However, even though most students understood the link, $17 \%$ of the students still were not sure after the project whether one ton of ore or one ton of smartphone scrap metal contains more gold. This implies that this approach of project-based learning does not reach all students, only a high percentage. Following Weinert (2001) this common finding can result from the fact that one teaching approach can rarely resemble the entire variety of competences among the students or not all members of the target group were stimulated by the offered approaches. In addition, students might not have realized the pure economic value of the gold content in their old mobile phones. This suggests Fig. 8 as 
the students shifted from donation and selling to recycling although these options are expressions of sustainable behavior, too. However, this was not the focus of this project.

In addition, obviously the awareness concerning the usage of resources and raw material was significantly enhanced through the project. At the beginning $28 \%$ of the students said they think that the worldwide natural gold deposits last for their lifetime, after the project only $7 \%$ were convinced about that (Fig. 7).

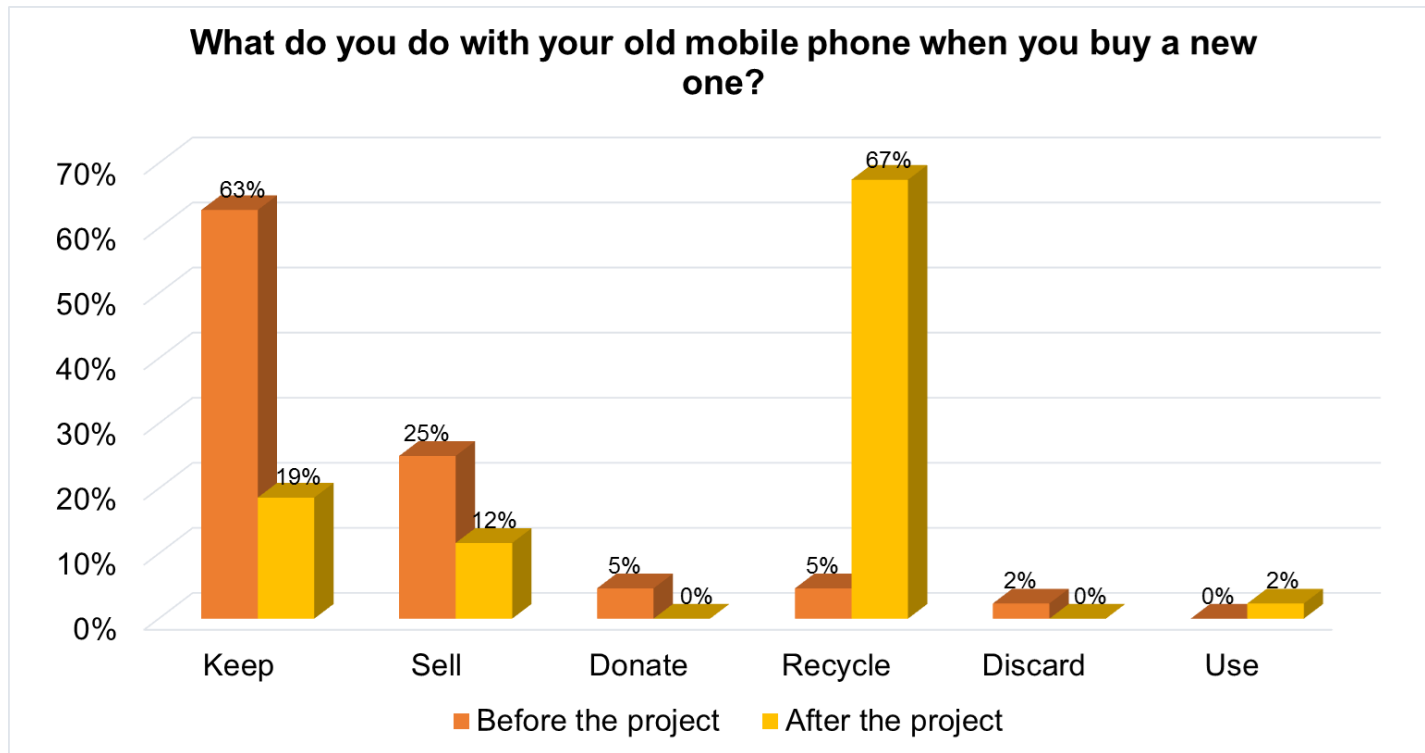

Figure 8. Distribution of answers to the question "What do you do with your old mobile phone when you buy a new one?"

In phase six of the project (Fig. 1) the students discussed the possibilities to increase the resource efficiency and sustainability at their school with their teacher. They got in touch with mobile phone companies and got recycling boxes, which they installed in their school. These are in use since then. Moreover, the students decided to give their presentation in the other classes in order for the other students to learn from then. This highlights that this project-based learning project is a best-practice example that changes the students' understanding and attitudes, because the students explore and understand the relation between sustainability and natural resources and the need for taking action.

\section{Conclusions}

Cooper and Murphy (2016) showed that there is a need for PBL best practice examples, because it fosters a culture of inquiry and creativity in the classroom. Therefore we designed a project in order to encourage students engage deeper learning driven through their own curiosity. The aim of our project has been to change students' attitude and increase the understanding and knowledge about resources and sustainability through PBL at school level, as these are one of the most important sociopolitical issues of today. In this project, the students realize that it is necessary to understand System Earth in its dynamic processes in order to understand the geological formation and global distribution of raw materials and their deposits, which are formed 
under variable physical and chemical conditions. They independently work out how much effort it is to explore, extract and process a single raw material from the rock. The students understand the historical dimensions of natural mineral deposits and determine the connection to sustainability. They question how valuable raw materials are and learn how to estimate the multidisciplinary knowledge required to manufacture technical equipment. The students appreciate the importance of recycling and research in these areas.

The students' appreciation of the project was obvious in their behavior and their efforts and input and it reflects in the evaluating questionnaire. By far most of the students reached the educational objectives. This project has considerably benefitted from the cooperation between school, university and the extracurricular location and we therefore would like to encourage teachers to cooperate with other institutions.

We understand this project as a best practice example for project based learning in education for sustainable development and here show that this approach enhances the knowledge, understanding and attitude about sustainability considerably. Considering the evaluation of the project, it is strongly recommended to imply such well-designed interdisciplinary project work into the educational curricula of appropriate school levels, in our case Year 9 students of a mid-level secondary school in Bavaria, Germany.

\section{Acknowledgements}

This project was funded by the Robert Bosch Stiftung, Germany. Anette Regelous would like to thank Dr. Stefan Krumm and PD Dr. Robert van Geldern for their assistance in the lab. We would also like to thank three anonymous reviewers for their thoughtful comments and efforts towards improving our manuscript.

\section{References}

Ballester, M., van Schaik, A. \& Reuter, M.A. (2017). Recyclability of EoL products Fairphone as an example. - Conference Contribution. Circular-CRM IdeaCamp and Workshop "Innovation and research in the e-waste recycling chain improving circular economy of critical raw materials", Aachen.

Bayerisches Landesamt für Umwelt (2017). Auf den Spuren des bayerischen Goldes. 172 pp., Hof, Germany.

Bayerisches Staatsministerium für Umwelt und Gesundheit Web Page. Handy Clever Entsorgen (in German). Available online: http://www.abfallratgeber.bayern.de/haushalte/ wertstoffsammlung/handy_laptop/index.htm.

BITKOM. Fast 86 Millionen Alt-Handys zu Hause (in German). Available online: https://www.bitkom.org/Presse/Presseinformation/100-Millionen-Alt-Handys-liegenungenutzt-zu-Hause.html.

Blewitt, J. \& Cullingford, C. (2004). The sustainability curriculum, the challenge for higher education. Earthscan. pp. 43-63 Sterling, S., pp. 157-166 Cowton, C.

Boud, D. (2012) Developing student autonomy in learning (second edition), Editor David Boud, Tayler and Francis, London and New York.

Chancerel, P. (2010). Substance flow analysis of the recycling of small waste electrical and 
Regelous, A., Holzförster, F., Stich, A. (2018) / Mobile phones as gold deposit - students explore....

electronic equipment. An assessment of the recovery of gold and palladium. - PhD-thesis, Technische Universität Berlin. ITU-Schriftenreihe 09/2010, Berlin.

Cooper, R. \& Murphy, E. (2016) Hacking project based learning. Published by Times 10, Hack Learning.org., Editor Jordan Young.

Fairphone (2017). Fairphone's report on recyclability. Does modularity contribute to better recovery of materials? - https://www.fairphone.com/wp-content/ uploads/ 2017/02/FairphoneRecyclabilityReport022017.pdf.

Federal Ministry of Education and Research announced on the 18th August 2014. http://ec.europa.eu /environment /index_en.htm)

Flick, U. Triangulation (2007). Eine Einführung (in German), 2nd ed.; VS Verlag für Sozialwissenschaften: Wiesbaden, Germany.

Hagelüken, C. (2009). "Urban Mining” ist wichtiger Beitrag zum Klimaschutz (in German). Dow Jones Trade News Emiss. 5, 14-16.

Hagelüken, C. (2011). Rohstoffsicherung durch Recycling - Chancen, Herausforderungen und Grenzen. - BMWi-Konferenz, 30.11.2011, Berlin. Available online: http://www.deutsche-rohstoffagentur.de/DERA/DE/Downloads/ DREP_2011_Hagelueken.pdf?_blob=publicationFile\&v=3.

Hagelüken, H. (2013). Recycling kritischer Metalle - Anforderungen, Verfahren und deren Grenzen (in German). Evangelische Akademie, Bad Herrenalb, Germany.

Harvard University Program on Survey Research, (2018) https://psr.iq.harvard.edu/book/ questionnaire-design-tip-sheet.

Haubrich, H. (2007) Geography education for sustainable development. Geographical views on education for sustainable development, in Geographiedidaktische Forschungen, Sibylle Reinfried, Yvonne Schleicher, Armin Rempfler (Editors), vol. 42, pp. 27-39.

Huckle, J. and Sterling, S. (2014). Education for sustainability, e-book, Earthscan, Taylor and Francis.

Huy, D., Andruleit, H., Babies, H.-G., Elsner, H., Homberg-Heumann, D., Meßner, J., Röhling, S., Schauer, M., Schmidt, S., Schmitz, M., Szurlies, M. \& Wehenpohl, B. (2015). Deutschland - Rohstoffsituation 2014, Bundesanstalt für Geowissenschaften und Rohstoffe, Hannover.

Jones, B. F., Rasmussen, C. M., \& Moffitt, M. C. (1997). Real-life problem solving. A collaborative approach to interdisciplinary learning. Washington, DC: American Psychological Association.

Jonson, R.B., Onwuegbuzie, A.J., Turner, L.A. (2007). Toward a definition of mixed methods research. J. Mixed Methods Res., 1, 112-133.

Kivinen, K. (2013) Education for sustainable development with a cross curriculum approach in line with European and international documents (https://kivinen.files.wordpress.com/ 2013/03/education-for-sustainable-development-european-schools.pdf.

Kuhlhay, J. (2013). Die Mediengeneration. Jugendliche, Ihre Medienkonsum und Mediennutzung- Ausarbeitung zum Forschungsstand (in German); Konrad Adenauer Stiftung: Berlin, Germany. 
Lehrberger, G. (1997). Geochemische Untersuchungen an den Goldvererzungen bei Oberviechtach-Unterlangau im Moldanubikum des Oberpfälzer Waldes. - Geol. Bavarica, 102, 207-227.Lettenmeier, M., Liedtke, C. \& Rohn, H. (2013). Roadmap to lifestyles of low resource consumption - New perspectives on sustainable transformation processes on the level of housholds. Resources. Submitted for publication.

Liedtke, C., Bienge, K., Wiesen, K., Teubler, J., Greiff, K., Lettenmeier, M. \& Rohn, H. (2014). Resource use in the production and consumption system - The MIPS approach. Resources 3 (3). 544-574.

Liedtke, C., Wiesen, K., Teubler, J., Bienge, K., Greiff, K., Lettenmeier, M. \& Rohn, H. (2013). Resource intensity analysis at micro level: Measuring dematerialization at product, company and household level. Resources. Submitted for publication.

MPFS (Medienpädagogischer Forschungsverbund Südwest) (2010). Jugend, Information,(Multi-)Media Basisstudie zum Medienumgang 12- bis 19-Jähriger in Deutschland (in German). Landesanstalt für Kommunikation, Stuttgart, Germany.

Schmidt-Bleek, F. (2007). Nutzen wir die Erde richtig? Von der Notwendigkeit einer neuen industriellen Revolution (in German). Fischer Taschenbuch, Frankfurt, Germany.

Sprenger, S. \& Nienaber, B. (2018) (Education for) Sustainable Development in Geography Education: review and outlook from a perspective of Germany, Journal of Geography in Higher Education, 42:2, 157-173, DOI: 10.1080/03098265.2017.1379057.

Tashakkori, A., Teddlie, E., Eds. (2002). Handbook of Mixed Methods in Social and Behavioral Research; Sage Publications: New York, NY, USA.

Thomas, J. W. (2000) A Review of research on project-based learning, $\mathrm{PhD}$, http://www.bie.org/index.php/site/RE/pbl_research/29.

Thomas, J. W., Mergendoller, J. R., and Michaelson, A. (1999). Project-based learning: A handbook for middle and high school teachers. Novato, CA: The Buck Institute for Education.

Vergara SE, Tchobanoglous G. (2012). Municipal solid waste and the environment: A Global Perspective. Annu Rev Environ Resour., 37: 277-309.

Weinert, F. E. (2001). Vergleichende Leistungsmessung in Schulen - Eine umstrittene Selbstverständlichkeit (in German). - In: Weinert, F.E. (Ed.): Leistungsmessungen in Schulen. Beltz: Weinheim, Germany, 17-31.

Welfens, M. A., Nordmann, J., Seibt, A. and Schmitt, M. (2013). Acceptance of mobile phone return programmes for increased resource efficiency by young people-experiences from a German research project. Resources, 2, 385-405; doi:10.3390/resources2030385.

Widmer R, Oswald-Krapf H, Sinha-Khetriwal D, Schnellmann M, Böni H. (2005). Global perspectives on e-waste. Environ Impact Assess Rev, 25:436-58.

Wilska, T. A. (2003). Mobile phone use as part of young people's consumption styles. $J$. Consum. Policy, 26, 441-463.

\section{Biographical Statement}

Anette REGELOUS is a researcher of geoscience education at the University of Erlangen- Nürnberg (FAU). She holds a doctoral degree in geochemistry from the MaxPlanck Institute für Geochemistry, Mainz, Germany, and a teacher training degree from 
Brunel University, London, in Physics. She teaches several courses at undergraduate and graduate level in geology. Her research focuses on geological education and mantle geochemistry.

Frank HOLZFÖRSTER is scientific director of the geoscience education center GEOZentrum at the Continental Deep Drilling Programme KTB in Windischeschenbach. He holds a doctoral degree in geology from University of Würzburg, Germany. He taught sedimentology at Rhodes University, South Africa, and University of Würzburg, Germany, before he changed into the extra-school and environmental education sector. His research concentrates on control factors of sedimentary systems and the implementation of geological knowledge in common education.

Alexander STICH is a teacher for geography and economics at the Hans-BöcklerSchule in Fürth, Germany. He is especially interested in resources, sustainability and resource efficiency. He has organised many field trips and extra-curricular projects for students at different age levels. One of his main aims is to show students how to live in harmony with the environment. 